\title{
Costa Rica: lessons from 30 years of forest and environmental policy
}

Rod Keenan ${ }^{1}$

As well as its recent success in World Cup football, Costa Rica is known for its mountains, beaches, forests and other natural landscapes and its 4.7 million people are considered the happiest people on the planet. The country is regarded as a world leader in policies to conserve, protect and sustainably manage forests. Despite its small size, it has high levels of biodiversity, particularly in its forests. High rates of deforestation and land degradation in the 1960s and 70s have been reversed to achieve an increase in forest cover over the last two decades to about $52 \%$ of the land area. How has this been achieved and what can other countries learn from the Costa Rican experience?

For the last two months I have been based at CATIE in Turrialba, Costa Rica, a centre of research and education for tropical agriculture and forestry, with projects addressing agriculture, land management, conservation and climate change across tropical Latin America and the Caribbean. I have spoken to researchers, people in government agencies and institutes, former policy makers and NGOs about the development of forest and environmental policy in Costa Rica.

With a land area of 5.1 million hectares (a little over half the size of Tasmania) Costa Rica straddles Central America, with Panama to the south and Nicaragua to the north. Much of the country is mountainous with a central volcanic cordillera, majestic rivers and steep slopes leading out to flatter coastal lowlands. The climate is highly variable, with the north drier, and currently in an extended drought, and higher rainfall areas in the mountains and to the south.

Costa Rica has been the long term home for a small indigenous population, that are now about $1 \%$ of the population and some of these communities continue to live traditional lifestyles in more remote parts of the country. 
European settlement had relatively humble beginnings compared with some Central American neighbours. Costa Rica was isolated from the main Spanish colonial centres and lacked the gold or silver of other Latin American colonies or a large indigenous population to exploit for labour. This led to a generally poorer, more individualistic, but more egalitarian, agrarian society, with higher levels of land distribution. The population was less than a million before World War 2. After civil war in 1948, a new constitution was developed guaranteeing universal suffrage. The dismantling of the military in this period and redirecting this expenditure into health and education is still a strong source of national pride.

For a long time, the economy was primarily based on coffee and bananas. Agricultural development was a national priority and forest land generally considered 'unused'. Growing international demand for beef and an increasing population were supported by government programs that provided relatively open access to forest land and support payments to convert forests to agriculture. This led to large scale clearance of forests from the 1950s through to the 1970s.

The turning point for forests came as global trade and economic conditions changed dramatically in the 1970s. High interest rates, international recession, low value of agricultural exports, more expensive imports (including oil) and the weakening of the Central American Common Market through war led to high fiscal deficits, inflation and decrease in national production. The country could no longer afford subsidies to expand the agricultural frontier for low value products. Grazing ceased but a considerable area of secondary forest, and some primary forest, is privately owned.

Addressing rural poverty was therefore major concern. In the 1980s, a forward thinking group of policy makers and researchers came together to forge a different development path based on a more educated population, industrialisation, urbanisation, intensification of agriculture for higher value products and recognising the value of water resources for urban development and hydro-electricity I. These leaders embraced the concept of sustainable development, designing strategies for this new development pathway. These ambitions were supported by the 'Washington consensus' ideology of privatisation of state assets and market-based policies for resource allocation.

\section{Valuing the environment}

Costa Rica has had a long-standing recognition of value of its biological assets. In the 1970s and 80s, international scientists worked with policy makers to focus attention of the implications of continuing forest loss for biodiversity and identified areas for designation as formal protected areas.
Innovative financial mechanisms were introduced to support payments for environmental values. Debt-fornature swaps were organised with donor countries in the 1990s based on studies of the value of Costa Rica's natural assets to the international community. The new Forestry Law of 1996 provided the framework for a system of payments for environmental services (PES) that changed incentives for reforestation from tax breaks, that were open-ended and largely went to the rich, to using part of the proceeds from a tax on petroleum (the 'polluter pays' principle) for forest protection, reforestation and sustainable forest management.

The environment has been a major public education theme and there is a high level of awareness of environmental values. The reputation of Costa Rica's spectacular natural environment and investment in hospitality education also led to growth in ecotourism ventures, with a focus on unique, high value experiences. Foreign visitors grew to 2.2 million in 2011.

\section{Issues and challenges}

Costa Rica has achieved much through the last 30 years. It has a high literacy rate (over 95\%), a focus on tertiary education, high-tech industries (major firms like Intel, Microsoft, Hewlett-Packard and Amazon have established operations in the country), health outcomes have improved, the economy has grown (with current GDP per capita nearly US $\$ 13,000$ ) and diversified and the environment has generally improved.

There are high levels of immigration as Nicaraguans, Colombians and others from the region seek work. This had added to social challenges. Unemployment is still high and there is a lack of jobs in regional areas, urban development is poorly controlled and there is a need for investment in better planning, public transport and road systems. Agricultural intensification is continuing to impact on erosion and water quality, for example pineapple production has been found to pollute domestic water supplies in some regions, and agriculture occurs on remarkably steep slopes.

The country has strong timber production potential but the focus on preservation has led to a decline in the local timber industry and it now a significant importer of timber. Some feel that the 'preservation culture' is too dominant, that sustainable use of forests is not considered a form of conservation and that the administrative arrangements do not support small scale timber production by local farmers. There is an interest in supporting a stronger timber industry based on plantations and managed native forests but it is unclear how this might proceed.

While there have been some celebrated examples of carbon financing for reforestation or forest protection, 
mobilising carbon payments from the international community has been slow, with many hurdles and impediments through international and national processes. More flexible approaches are required to build this form of forest investment. The country has set the goal of becoming carbon neutral by 2021 but, with a growing industry and more cars on the road, it is not clear how this will be achieved.

There is considerable debate over the design of payments for environmental services. Some argue that it is not truly market based, or well targeted at the primary causes of forest loss, and that payments provide little benefit to rural poor. It has also been argued that these payments are obstacles to further timber processing activities as landholders become complacent and are happy to simply accept PES without finding ways of engaging with industry and adding value through sustainable forestry practices.

In general, resources for management and conservation of natural resource are still low. In many situations the value of PES is not sufficient to offset the potential value of agricultural production and forest conversion is still occurring, often by stealth through incremental forest modification and clearing.

Economic development remains a priority. Jobs for rural people and making greater use of the educated population are real challenges. Growth in tourism has been important but the dominance of this sector has made the country more susceptible to international conditions and less resilient to shocks in key markets for international visitors.

\section{Lessons for others}

So what can other countries learn from the Costa Rican experience? Clearly a stable representative government, robust finance, insurance and legal institutions, a focus on peace and wider prosperity, addressing conflict and building political consensus on key objectives and strategies have been the basis of the Costa Rica's success.

Investment in education and training, the willingness to innovate in policy (using the power of the market to drive investment) and strong support for science and evidence in policy have also been important contributors to better policy. Taking advantage of opportunities to mobilise carbon payments and other forms of international finance has benefited forest conservation and protection.

\section{The future}

Many now feel that Costa Rica at the cross roads. The reforms in the 1980s and 1990s provided the platform for major economic and environmental policy developments with significant social, environmental and economic achievements in the last 20 years. However, the situation is now different and the challenge for the newly-elected Solis government is to put in place the processes to design a new wave of reforms to address current challenges.

This includes dealing with the 'wealth trap', as the country has become richer and its traditional comparative advantages decline. The focus on environment remains important but it needs remain strongly linked to sustainable economic development. This can happen through higher value agriculture commodities and manufactures (including producing more timber and products for domestic use), encouraging development of different service sectors, new forms of tourism as the cost base increases, managing energy demand and generating alternative sources of sustainable supply such as geothermal and solar and building the tax base for investment in public transport and infrastructure.

For forests and the environment, the National Government has indicated interest in providing more support for domestic wood supply and using this to support lower cost housing with a lower carbon footprint, but the appetite in the congress and engagement with industry (by forest owners and the government) needs to be rebuilt. The PES scheme needs to be redesigned to more effectively target payments to achieve increases in the supply of services such as water, catchment protection and avoided carbon emissions or sequestration. There needs to be stronger enforcement of regulation and incentives for improved management of industrial waste and chemical use in agriculture.

Costa Ricans can be rightly proud of their achievements. The people are warm, genuinely friendly, intelligent and confident about their place in the region and the world. With the right policies, Costa Rica can continue to set an example in sustainable development for the next thirty years. Pura vida! 